\title{
PALEONTOLOGY AND DIAMONDS: GEOLOGICAL ENVIRONMENTS ASSOCIATED WITH KIMBERLITE EMPLACEMENT, LAC DE GRAS, NORTHWEST TERRITORIES, CANADA
}

\author{
Sweet $\mathbf{A R}^{1}$, Stasiuk LD ${ }^{1}$, Nassichuk WW ${ }^{1}$, Catuneanu $\mathbf{O}^{2}$, McIntyre, DJ ${ }^{3}$ \\ ${ }^{1}$ Natural Resources Canada; ${ }^{2}$ University of Alberta, Canada; ${ }^{3}$ Manuka Palynologic Consulting, Canada
}

\begin{abstract}
Abundant fossil spores, pollen and marine algal cysts from individual shale xenoliths and finer clastic matrix in kimberlite samples allow the determination of depositional environments and ages of rock units in the inferred but now eroded cratonic sedimentary cover. Through analysis of depositional environments it is quite clear that the interior seaway extended over the craton in the early Late Cretaceous and again, at least partially, in the late Campanian, but by the Maastrichtian it had withdrawn, leaving a terrestrial landscape into which most Lac de Gras kimberlites erupted. The ages allow correlation of sequences in the Lac De Gras region with those of western Canada. Plant microfossils characteristic of latest Turonian through early Campanian, latest Campanian through early Maastrichtian, and late Paleocene ages have not been confirmed in the Lac de Gras xenoliths suggesting depositional hiatuses occurred within the now eroded sedimentary cover. During some of these times, erosion may have been removed strata leaving behind only enhanced thermal maturity profiles as a signature of their former presence. The synchroneity between the emplacement of the Greenland mantle plume and the concentration of kimberlite eruptions in the late Paleocene and earliest Eocene is discussed.
\end{abstract}

\section{INTRODUCTION}

Shale and mudstone xenoliths in the crater fill of kimberlite pipes in the Las de Gras area (Fig. 1) contain a record of a now eroded sedimentary cover. Microscopic plant fossils (miospores and dinoflagellates) provide: 1 ) the ages of rocks in the pre-eruptive sedimentary cover, 2) inferrences of maximum ages for kimberlite emplacement; and, 3) the interpretation of depositional environments. From such evidence Nassichuk and McIntyre $(1995,1996)$ and Nassichuk and Dyck (1998) determined that pre-eruptive strata included marine Albian to Maastrichtian rocks and nonmarine Paleocene rocks and concluded that the Interior Seaway had extended farther eastward than previously thought. Similar conclusions were reached by Doyle et al. (1998), Graham et al. (1998), McKinlay et al. (1998).

This study builds on the previous work with the objectives of: 1) recognizing major hiatuses that reflect uplift events; 2) correlating Lac de Gras area stratigraphy with Cretaceous and
Paleogene sucessions regionally in order to provide an analog for probable thickness of the Cretaceous and Paleocene sedimentary cover over the Slave Province; 3 ) illustrating the paleogeographic and phytogeographic implications of the xenoliths preserved in kimberlites of the Lac de Gras region; 4) discussing tectonic mechanisms involved in base level changes and the regional geological context during kimberlite emplacement.

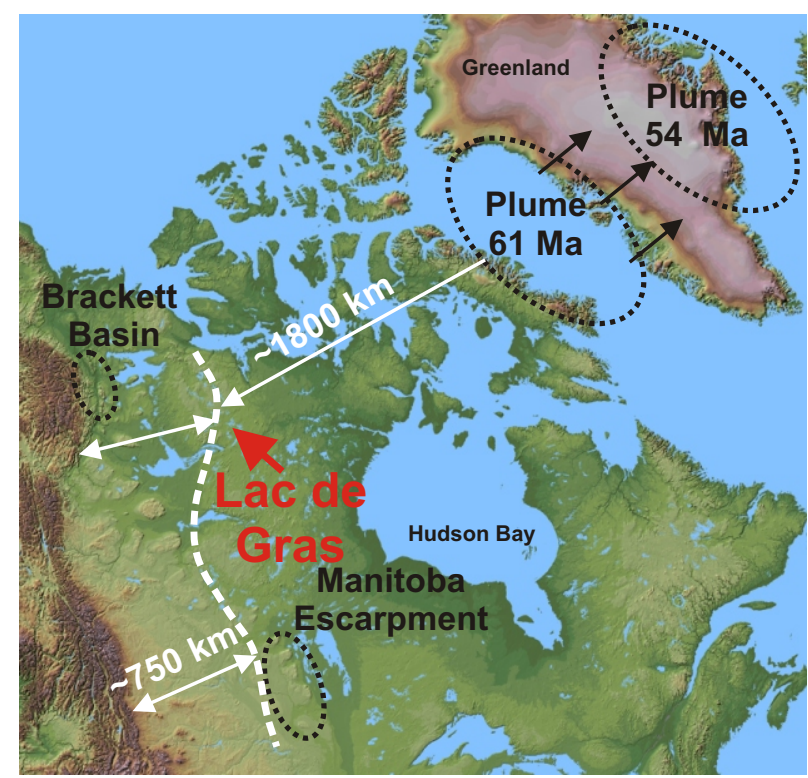

Figure 1. Locality map showing a equal-distance trace (white dashed line) following the orogenic outline, and the position of mantle plumes during the late Paleocene and early Eocene.

\section{Materials and Methods}

The absolute ages used herein are approximated from Berggren et al. (1995). The palynological component of this study is based on samples from 9 different craters (DO18-08, DO18-12, DO18-13, EG-130-1, 93-A25-1B, 94-ABZ-1, 93-T14-1, and ECH95-16 (Scorpion) and 35 samples from post-eruptive sediments (BHP bore holes "Giraffe pipe; CH93-29; CH93-13; KBS-3). Paleoenvironmental interpretations based on the microfossils present are complemented evidence from the types of kerogen present. 


\section{INFERRED CHRONOLOGICAL UNITS AND PALYNOLOGICAL ASSEMBLAGES}

\section{Middle to Late Albian Age ( 100-105 Ma)}

Two samples from the DO18-12 bore hole contained rich assemblages of terrestrial spores (including Concavissimisporites punctatus, Concavissimisporites variverrucatus, Cooksonites, Distaltriangulisporites spp., Kuylisporites lunaris, Lycopodiumsporites expansus, L. marginatus, Sestrosporites pseudoalveolatus, Tigrisporites scurrandus, T. reticulatus, Trilobosporites humilis and $T$. trioreticulosus), gymnosperm pollen (including Nicholsipollis mimas, Rugubivesiculites microsaccus and R. rugosus) and monocolpate and tricolpate angiosperm pollen, and few to numerous marine algae (including Luxadinium propatulum, Ovoidinium scabrosum and Ginginodinium evitii). A marginal marine to near-shore marine depositional environment is inferred, implying both the eastward extension of the Mowry Sea (Williams and Stelck, 1975) into the Lac de Gras region (Fig. 2), and a proximity to land.
Early? to Mid Cenomanian? ( 95-98? Ma)

Several samples in the DO18-08 and DO18-12 bore holes contain a generalized spore and pollen assemblage anddinoflagellates that do not allow recognition of subdivisions within the Cenomanian or even between the late Albian and Cenomanian. The precise age of these samples is therefore inconclusive leaving open the possibility that this chronological interval spans a hiatus (Fig. 3).

\section{Mid Cenomanian? to Turonian ( 90-95 Ma)}

Mid Cenomanian to Turonian assemblages occur in all the kimberlitic bore holes and in the majority of the samples. The assemblages are rich in marine algae ( including Chatangiella ditissima, Heterosphaeridium difficile, Isabelidinium magnum and Trithyrodinium suspectum), and consistently contain Rugubivesiculites "tuberculate" and tricolporate angiosperm pollen. The abundance and diversity ofdinoflagellates and the dominance of lipid-rich amorphous kerogen indicates open and deep marine waters implying the transgression of the

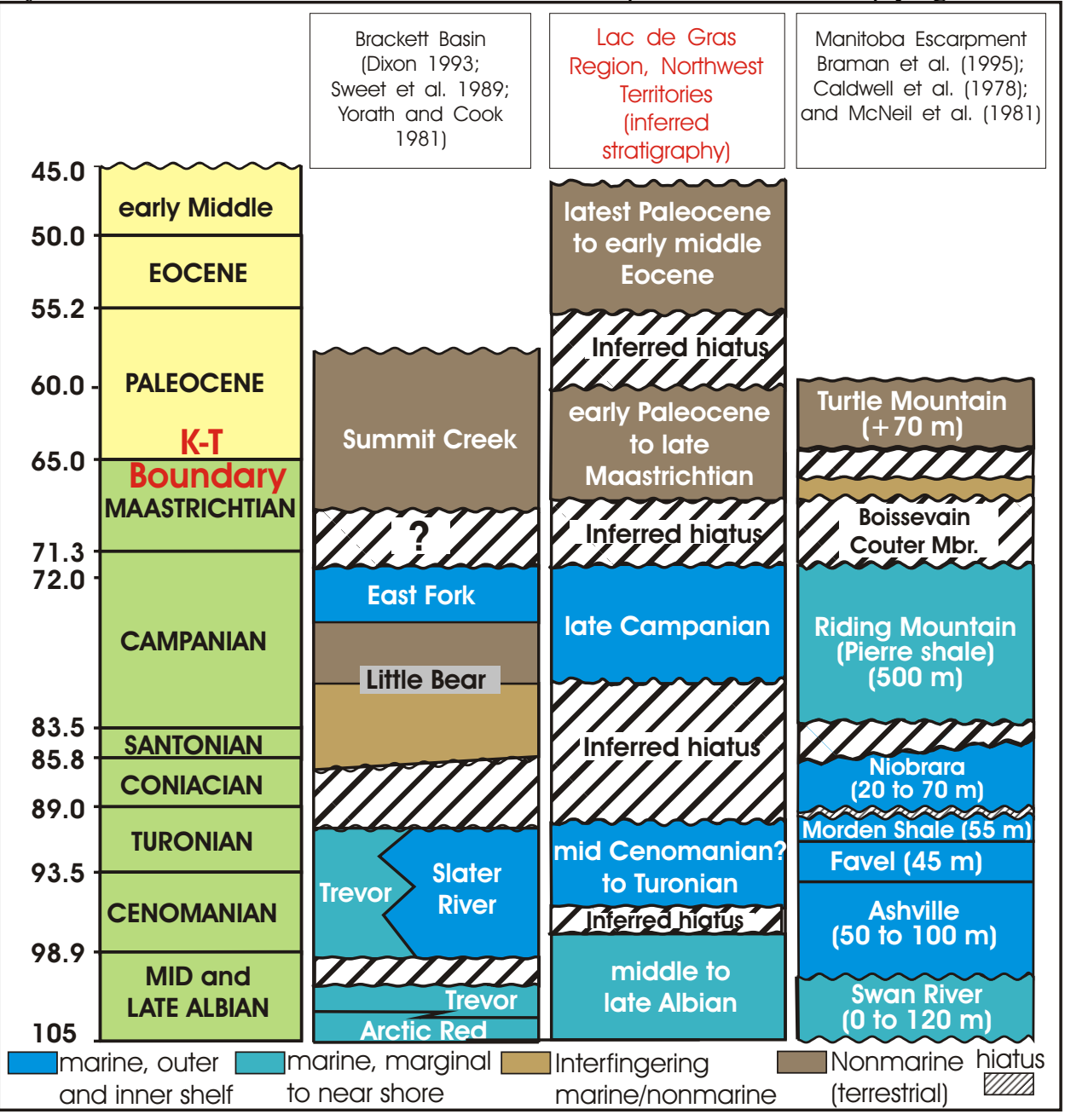

Figure 2. Time scaled, lithostratigraphic sections for the Brackett Basin, Manitoba Escarpment and that inferred for the Lac de Gras region. Unit thicknesses have been included on the Manitoba Escarpment section as it is a similar distance from the orogen as Lac de Gras. 
continental seaway over the northwestern part of the craton during this time (Fig. 2).

\section{Late Turonian?, Coniacian, Santonian and Early Campanian ( 80-90 Ma)}

Assemblages identifying these ages were not encountered and it is possible that this absence is indicative of a significant hiatus (Fig. 2).

\section{Late but not Latest Campanian ( 73-80 Ma)}

Two samples from near the base of EG-130-1 bore hole are rich in both angiosperm pollen (including Aquilapollenites sp. cf. A. Trialatus, Expressipollis, Fibulapollis, Loranthacidites pilatus, Pseudoplicapollis and Translucentipollis) and marine algae (including Chatangiella ditissima, Dinogymnium sibiricum, Fromea chytra, Horologinella sp., and Laciniadinium williamsii), which indicate a late Campanian age. The angiosperm pollen are allied with those in correlative strata in the Anderson Plains (McIntyre, 1974) and the Arctic Islands (Felix and Burbridge, 1973). The late Campanian interior seaway presumably restricted pollen input from the west and southwest leaving emergent land to the north and northeast as the source area. The upper age limit on this assemblage is then constrained by the timing of the withdrawal of the interior seaway.

\section{Latest Campanian to Early Maastrichtian (73 to 69 Ma)}

A number of species (Aquilapollenites augustus, A. oblatus, A. quadrilobus, A. reticulatus, Callistopollenites radiostriatus, Cranwellia rumseyensis, Kurtzipites trispissatus, Liliacidites complexus, Orbiculapollis lucidus, Pulcheripollenites krempi, Triprojectus magnus, T. unicus and Wodehouseia gracile), known from both the Maastricthian and early late Maastrictian, occur together with the definitive late Maastrichtion taxa listed below. As none of these are specifically indicative of a latest Campanian or early Maastrichtian age, it might be assumed that a hiatus occured during all or most of this time (Fig. 2) .

\section{Late Maastrichtian to Early Paleocene? (61 to 69 Ma)}

The major pollen and spore component of seven samples from the EG-130-1, 94-AB2-1 and 93-T14-1 bore holes is typical of late Maastrichtian sediments in the Western Canada and Brackett basins (includes Aquilapollenites conatus, A. delicatus?, A. reductus, Cranwellia sp. (5 colps), Ephedripites multipartitus, Mancicorpus notabile, Myrtipites scabratus, Porosipollis porosus, Triporopollenites plektosus Wodehouseia octospina, and Wodehouseia spinata). This change to a western or southwestern pollen source is consistent with a latest Campanian/early Maastrichtian interior seaway withdrawal. A few taxa, Alnipollenites, Betulaceae pollen and Paraalnipollenites alterniporus suggest that clasts of early Paleocene age are also present. Recycled Cretaceous spores and dinoflagellates, Permo-Triassic pollen and Carboniferous spores are commonly present.

\section{Late Paleocene (56 to $61 \mathrm{Ma}$ )}

A hiatus is inferred for this time (Fig. 2), as unambiguous late Paleocene assemblages were not identified.

\section{Post-eruptive Latest Paleocene? to MidEocene ( 45-56 Ma)}

Angiosperm pollen assemblages from the BHP bore holes "Giraffe pipe" ; CH93-29, CH93-13 and KBS-3 record the post-eruptive phase of crater fill. Nassichuk and McIntyre (1995) reported late Paleocene ages from the three latter bore holes, which is now revised to early Eocene based on the finding of Platycaryapollenites swasticoidus and a gemmate monolete spore, both indicative of Eocene. More recently a well developed late early Eocene and/or early middle Eocene terrestrial pollen and spore assemblage has been documented from bedded lacustrine and swamp, post-eruptive crater fill sediments (see Hamblin et al., 2003, this volume).

\section{GEOLOGICAL CONTEXT FOR THE POST- ERUPTIVE SEDIMENTARY COVER}

A pattern of base level change during deposition of the sedimentary cover in the Lac de Gras region can be inferred from the ages and depositional environments recorded by palynological assemblages and kerogen types (Fig. 2). For comparison, and to place the interpreted sequences into a regional context, the Albian through Paleocene sequences along the Manitoba Escarpment and contemporaneous sequences in the Brackett Basin are also illustrated (Fig. 2). The Manitoba Escarpment is more or less along depositional strike and the Brackett Basin is up depositional dip from Las de Gras (Fig. 1). The total maximum thickness of the succession along the Manitoba Escarpment is approximately $1000 \mathrm{~m}$. This thickness is of the order necessary to achieve the thermal maturity of Albian and early Late Cretaceous sediments in the Lac de Gras area (see Stasiuk et al., 2003, this volume).

Several of the hiatuses in the Manitoba Escarpment and Brackett Basin successions are in comparable positions to those inferred for the interpreted sedimentary cover in the Lac de Gras area (Fig. 2). Exceptions are the presence of a late late Maastrichtian to earliest Paleocene hiatus in Manitoba and a much more extensive latest Turonian to early Campanian hiatus inferred for the Lac de Gras region. This latter hiatus may well represent a time when accumulated sedimentary cover, which left its mark by the elevated thermal maturity of Albian and early Late Cretaceous sediments, was partially removed. Equally, younger hiatuses may also represent times of partial removal of accumulated sedimentary cover.

Notwithstanding these probable erosional events, there were at 
least four Late Cretaceous rock sequences still present in the early Tertiary. If one were to take the number of samples with assemblages assignable to specific chronological units as an indication of their relative thickness, late Cenomanian to Turonian sediments would be by far the thickest and Albian and late Campanian sediments the thinnest. In addition, the proportions of various aged clasts in different pipes and/or bore holes varies. The dominant assemblages in the EG-130 and A2 holes are of late Maastrichtian/Paleocene age whereas those from DO18, T14 and A25 are of Albian and/or Cenomanian/Turonian age. This suggests that there may have been corresponding variations in the sedimentary cover over the Lac de Gras area, either through differential erosional events or restricted areas of deposition.

\section{LARGE AMPLITUDE REGIONAL CONTROLS ON BASE LEVEL CHANGES}

The formation of accommodation for the deposition of sedimentary stacks approaching $1500 \mathrm{~m}$-thick (see Stasiuk et al., 2003, this volume) over what is now exposed craton requires the manifestation of continental scale subsidence of comparable magnitudes. The geographic position of the study area (Fig. 1), as well as the general stratigraphic and paleoenvironmental similarities with the age-equivalent succession preserved in the Manitoba Escarpment (Fig. 2) argue that
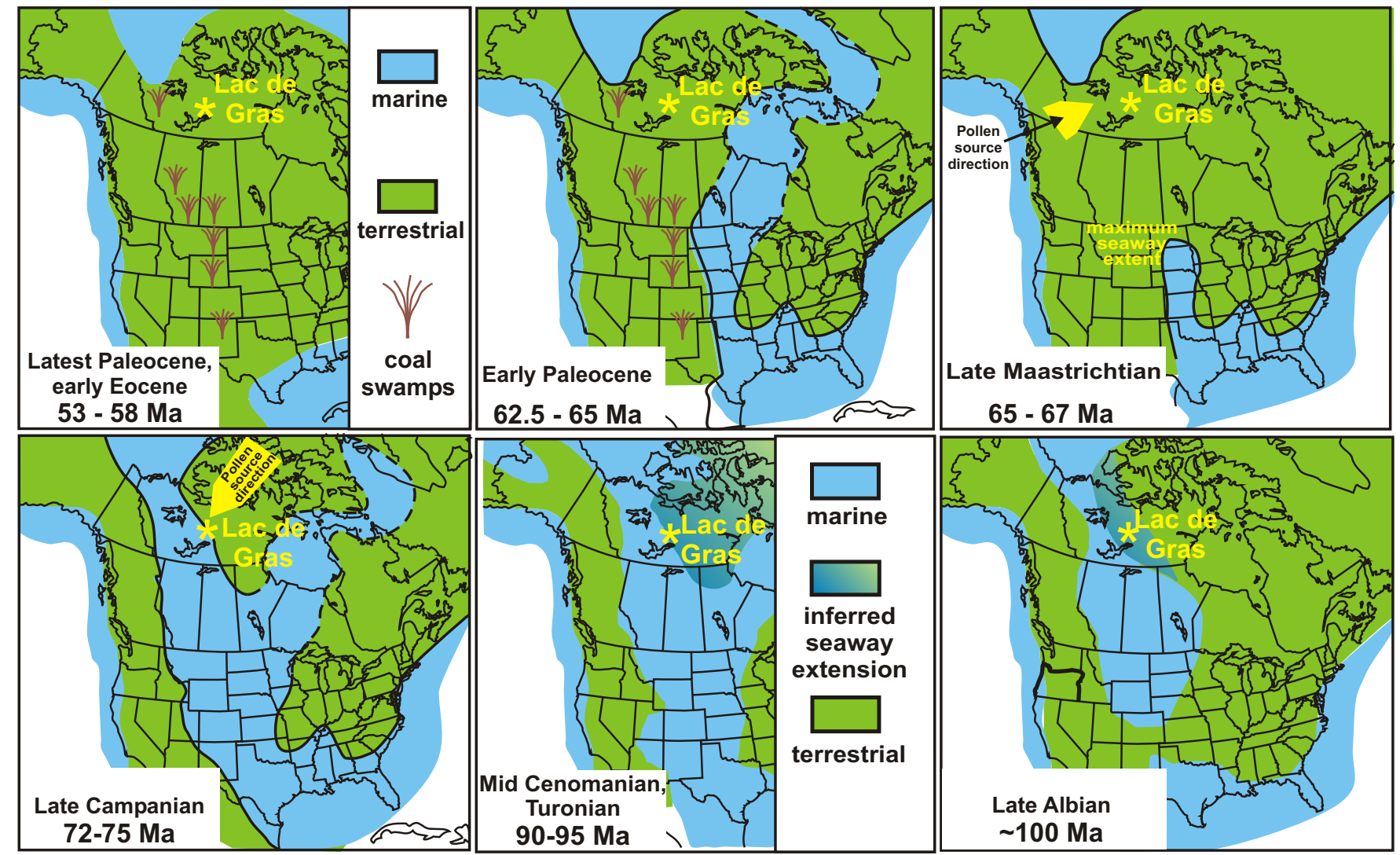

the Lac de Gras region was once part of the same western Canada foreland system. Accommodation space in distal forelands, generally subject to flexural uplift of the forebulge, is attributed to subduction-related dynamic loading, which generates long-wavelength subsidence on continental scales (Mitrovica et al., 1989; Gurnis, 1992). Dynamic subsidence is documented to have been an important factor in the accumulation and preservation of relatively thick sequences in the distal part of the southern Canadian foreland system (Catuneanu et al., 1997), so it is likely that the same mechanism generated the inferred amount of accommodation in the Lac de Gras region. Changes in the amount of dynamic loading, as well as renewed flexural uplift of the distal foreland in relation to thrusting episodes in the Cordilleran belt, can explain the inferred stratigraphic hiatuses.

In addition to obvious regional extension, another tectonic factor may have affected the Lac de Gras area during late Paleocene and early Eocene time. Starting at about 61 Ma the emplacement of a plume in the vicinity of Baffin Island is evidenced by the initiation of uplift and volcanism followed by basalt flows and subsidence (Harrison et al., 1999). Plume driven uplift can occur at scale $=\mathrm{s}$ of 1000's of $\mathrm{km}$, as can associated dikes (Harrison et al., 1999), well within the range of the Lac de Gras area, especially during the earlier phases of

Figure 3. Paleogeographic maps for six time units mostly modified after Williams and Stelck (1975). 
plume activity (Fig. 1). From 61 Ma to 54 Ma the position of the plume shifted to the eastern margin of Greenland. This timing of an active mantle plume under the Baffin Island/Greenland region corresponds with the inferred ages for many of the Lac de Gras kimberlites. Therefore, the late Paleocene-early Eocene interval seems to have been a time of tectonic instability dominated by continental scale plumedriven uplifts, which may explain the erosion of much of the distal foreland fill in the Lac de Gras region and the timing of kimberlite emplacement.

\section{ACKNOWLEDGEMENTS}

The skill of Brenda Davies and Ramakant Kalgutkar in preparing samples for palynological analysis is recognized. James White's careful review of the manuscript led to its improvement. Kim Dunn cheerfully applied her expertise to formatting the text and figures.

\section{REFERENCES}

Berggren, W.A., Kent, D.V., Aubry, M-P., Hardenbol, J., 1995. Geochronology, time scales and global stratigraphic correlation. Soc. Sed. Geol., Spec. Pub. 54.

Braman, D.R., Sweet, A.R., Lerbekmo, J.F. 1999. Upper Cretaceous-lower Tertiary lithostratigraphic relationships of three cores from Alberta, Saskatchewan, and Manitoba, Canada. Can. J. Earth Sci., 36, 669-683.

Caldwell, W.G.E., North, B.R., Stelck, C.R., Wall, J.H. 1978. A foraminiferal zonal scheme for the Cretaceous System in the Interior Plains of Canada. In: Stelck, C.R., Chatterton, B.D.E. (Eds.), Western and Arctic Canadian Biostratigraphy. Geol. Assoc. Canada, Spec. Paper 18, 495-575.

Catuneanu, O., Beaumont, C. and Waschbusch, P., 1997. Interplay of static loads and subduction dynamics in foreland basins: Reciprocal stratigraphies and the Amissing@ peripheral bulge. Geology, v. 25, no. 12, p. 1087-1090.

Dixon, J., 1993. Regional unconformities in the Cretaceous of north?west Canada. Cret. Res., 14, 17 ?38.

Doyle, B.J., Kivi, K., Scott Smith, B.H., 1998. The Tli Kwi Cho (DO27 and DO18) Diamoniferous Kimberlite complex, Northwest Territories, Canada. In: Dawson, J.B. Volume, Proc. of 7th Int. Kimberlite Conf., 1, A-K, 194-204.

Felix, C.J., Burbridge, P.P. 1973. A Maastrichrian age microflora from Arctic Canada. Geosci. and Man, 7, 1-29.

Graham, I. Burgess J.L., Bryan, D., Ravenscroft, P.J., Thomas, E. Doyle, B.J., Hopkins, R., Armstrong, K.A., 1998. Exploration history and geology of the Diavik kimberlites, Lac de Gras, Northwest Territories, Canada. In: Dawson, J.B. Volume, Proc. of 7th Int. Kimberlite Conf., 1, A-K, 194-204.

Gurnis, M., 1992. Rapid continental subsidence following the initiation and evolution of subsidence. Science, v. 255, p. 1556-1558.

Harrison, J.C., Mayr, U., McNeil, D.H., Sweet, A.R., McIntyre, D.J., Eberle, J.J., Harington, C.R., Chalmers, J., Dam, G., Nohr?Hansen, H., 1999. Correlation of Cenozoic sequences of the Canadian arctic region and Greenland. Bull. Can. Pet. Geol. 47, 223?254.

Kedves, M., 1982. Palynology of the Thanetian layers of Menat. Paleontographica Abt. B. 182, 87?150.

McIntyre, D.J., 1974. Palynology of an Upper Cretaceous section, Horton River, District of Mackenzie, N.W.T. Geol. Surv. Canada Pap. 74-14, 1-57.
McKinlay, F.T., Scott Smith, B.H., de Gasparis, S., Kong, J., 1998. Geology of the recently discovered Hardy Lake Kimberlites, NWT. Proc. of 7th Int. Kimberlite Conf., Cape Town, South Africa, April 1998, Extended Abstracts, p. 564-566.

McNeil, D.H., Caldwell, W.G.E., 1981. Cretaceous Rocks and their foraminifera in the Manitoba Escarpment. Geol. Assoc. Canada, Spec. Paper 21.

Mitrovica, J.X., Beaumont, C. and Jarvis, G.T., 1989. Tilting of continental interiors by the dynamical effects of subduction. Tectonics, v. 8, p. 1079-1094.

Nassichuk, W.W., Dyck, D.R., 1998. Fossils recovered from kimberlite pipes in the Lac de Gras Field, Slave Province, northwest Canada; Geological implications. Proc. of 7th Int. Kimberlite Conf., Cape Town, South Africa, April 1998, Extended Abstracts, p. 612-614.

Nassichuk, W.W., McIntyre, D.J., 1995. Cretaceous and Tertiary fossils discovered in kimberlites at Lac de Gras in the Slave Province, Northwest Territories. In; Current Research 1995-B; Geol. Surv. Canada, 109-114.

Nassichuk, W.W., McIntyre, D.J., 1996. Fossils from diamondiferous kimberlites at Lac de Gras, N.W.T.: Age and paleogeography. In: A.N. LeCheminant, D.G. Richardson, R.N.W. Dolabio, and K.A. Richardson (Eds.); Searching for Diamonds in Canada; Geol. Surv. Canada., Open File 3228, 43-46.

Sweet, A.R., Ricketts, B.D., Cameron, A.R., Norris, D.K., 1989. An integrated analysis of the Brackett coal basin, Northwest Territories; Geol. Surv. Canada, Paper 89?1, 85?99.

Williams, G. D., Stelck, C.R., 1975. Speculations on the Cretaceous Paleogeography of North America. In: W.G.E. Caldwell (Ed.) The Cretaceous System in the Western Interior of North America. Geol. Assoc. Canada, Spec. Paper 13, 1?20.

Wing, S.L., Harrington, G.J., 2001. Floral response to rapid warming in the earliest Eocene and implications for concurrent faunal change. Paleobiology, 27, 539 ?563.

Yorath, C.J., Cook, D.G., 1981. Cretaceous and Tertiary stratigraphy and paleogeography, Northern Interior Plains, district of Mackenzie. Geol. Surv. Canada, Mem. 398.

Arthur R. Sweet, Ph.D., Natural Resources Canada, 3303-33rd St NW, Calgary, Alberta T2L 2A7; asweet@NRCan.gc.ca 